\title{
Phenotypic Variability of Some Maize Inbreed Lines from ARDS Turda
}

\author{
Roxana ȘUT GHERMAN ${ }^{1}$, Voichița HAȘ ${ }^{2}$, Andrei VARGA ${ }^{1,2}$ Ana COPÂNDEAN ${ }^{2,}$ Ioan HAȘ ${ }^{1,2}$ * \\ ${ }^{1}$ Faculty of Agriculture, University of Agricultural Sciences and Veterinary Medicine Cluj-Napoca \\ ${ }^{2}$ Agricultural Research and Development Station Turda \\ * corresponding author: ioanhas@yahoo.com
}

Bulletin USAMV series Agriculture 72(1)/2015

Print ISSN 1843-5246; Electronic ISSN 1843-5386

DOI 10.15835/buasvmcn-agr: 11168

\begin{abstract}
The inbreed lines collection from the Agricultural Reseach and Development Station Turda include inbreed lines created on the station, but also lines with a different origin. The aim of this paper is the study of the phenotypic variability between maize inbreed lines for vegetative traits of the plant and the traits of ear and kernels: plant height, ear height, number of leaves/plant, number of branches/tassel, reaction to different types of cms, ear lenght, number of rows, number of kernels/row, kernels type, kernels color, cob color and the chemical composition of the grains. Using the phenotypic characterisation there are identified new sources for some favorable traits that can be used for the breeding of competitive hybrids. The study also refered to the number of days between sowing to silking, and sowing to physiological maturity.On this study there were analyzed over 471 dent and flint inbreed lines from ARDS Turda. The inbreed lines were studied on the field regarding vegetative traits: the plant height, the ear height, number of leaves/plant and the number of branches/tassel. On the laboratory there were studied the ear and kernels traits. Using all the data obtained there will be choosen some inbreed lines that are used for the maize hybrids breeding programs.Most inbreed lines belong to the dent variety and most lines have a short or medium long ear. It was also noticed a high proportion of lines with 14-18 kernel rows.There is a high variability between the lines regarding the plant height, ear hight and the number of kernels/row, and a very high variability for the number of branches/tassel.The inbreed lines from ARDS Turda can be used as parents for the commercial hybrids. The variability between the lines makes them more valuable, due to the fact that there are a lot of sources for maize improvement programs.
\end{abstract}

Keywords: ear,inbreed lines, kernels, variability

\section{INTRODUCTION}

The Research and Development Station Turda owns on its colection over 1000 inbreed lines, and more than half of these lines were created on the maize breeding laboratory from the institution. The inbreed lines colection also includes inbreed lines from other research station from the country ( National Agricultural Research and Development Institute Fundulea, ARDS Suceava, ARDS Lovrin, ARDS Podul Iloaiei) and from abroad (Republic of Moldova, U.S.A., Germany, Italy, France, Canada, Poland). These lines were obtained after germplasm exchange programms, and had a big influence on the genetic diversification of the genotypes used as parental lines for maize breeding.

The breeding process of maize inbreed lines at ARDS Turda included several stages (Haș et al., 1999), of which the most important are:

- choosing the initial material;

- creation of inbred lines after having performed selection through various methods under controlled self-pollination;

- testing the value of inbred lines using crossings with testers and checking general and specific 
combining ability and the ability of transmiting traits of agronomic interest to the descendent.

The initial matherial used for breeding new lines at ARDS Turda is represented by varieties and local populations, synthetic populations and composites, first cycle matherials crossed with elite lines, crossings or backcrossings for breeding specific traits of elite lines, oligogenes sources, commercial hybrids (HAȘ et al., 1999).

Using local populations may encounter some difficulties due to the necessity of applying recurent selection methods in order to improve it with favourable genes before the use as initial matherial (JUGENHEIMER, 1976; HALLAUER and MIRANDA, 1981).

On the last years progress has been made regarding the use of synthetic populations as starting material due to complementary recombinant character of some inbred lines. At Turda, in the synthetic populations, recurrent selection was made to improve characters such as resistance to low temperatures, Ostrinia nubilalis atack resistance, production capacity and resistance to lodging (HAS et al., 1999).

Initial material represented by commercial hybrids from the USA, France and Germany has been a valuable source of genes for many characters (HAS, 1992; HAȘ et al., 1999) among which may be mentioned: few branches tassel, but rich in pollen, very good combining ability, reduced leaf area, but prolonged photosynthetic capacity, thin, elastic talk, resistance to lodging and brokenness.

"Corn Belt" germplasm has a particular importance to improve inbred lines in Europe and the USA, due to productivity genes and other genes of agronomic interest is used as starting material in the creation of inbred lines at ARDS Turda (CĂBULEA et al., 1999).

In the process of creating inbred lines it has been considered the hybrid ideotype to be obtained from crosses of inbred lines and, if this ideotype is not found the lines are removed. Maize breeding objectives have changed over time depending on the evolution of culture technologies, expanding into new culture area, the evolution of pathogens and due to new discoveries in genetics, biotechnology, biochemistry and physiology (CĂBULEA, 1987; CĂBULEA et al., 1999).

The purpose of this paper is to analyze the variability between maize inbred lines from the collection of ARDS Turda regarding the vegetation period, expressed by the number of growing degree units from sowing to the appearance of stigmata and the number of growing degree units from sowing date and physiological maturity, some plant characters and characters of ear and kernels, all of which are chosen according to their agronomic importance.

\section{MATERIALS AND METHODS}

The biological material was represented by 471 maize inbreds lines from ARDS Turda.

There were performed phenological observations and measurements for plant, cob and kernels for 17 characters. These characters refer to the vegetation period, as well as some characters of the plant (4), ear (8) and kernel (3). Plant characters:

- plant height;

- ear height;

- no. of leaves/plant;

- no of branches/tassel.

- Ear and kernel character:

- ear lenght;

- no of rows;

- no of grains/row;

- ear weight;

- percent of grains/ear;

- weight of 1000 grains;

- kernels depth;

- thick of cob;

- kernels type;

- kernels color;

- cob color.

The coefficient of variation (CV\%) was calculated using the formula (CEAPOIU, 1968):

coefficient of variation $(\mathrm{s} \%)=\frac{\text { standard deviation }}{\text { mean of each trait }} \times 100=\%$

It has also been carried out the histogram frequency for each character (ARDELEAN, 2008).

\section{RESULTS AND DISCUSSION}

For 471 inbred lines created at SCDA Turda, there were made observations on the degree of variability that may exist between the characters of the plant, the ear and kernels, and the vegetation period.

After analyzing the variance it has been found high variability regarding the period between sowing and appearance of stigmas, with a minimum 
of 492 growing degree units on the sterile lines T9 $\mathrm{cms} \mathrm{T}$ and $\mathrm{T} 9 \mathrm{cms} \mathrm{C}$ and a maximum of 745 growing degree units at TA 409. Physiological maturity values were between 911 and 1209 growing degree units. The minimum period for physiological maturity was calculated for T 139 inbreed line and the maximul for $\mathrm{T} 381$. Given the diversity of the period between sowing and appearance of stigmas and the physiological maturity it can be said that the lines from the collection of inbred lines of the maize breeding laboratory belong to all maturity groups.

Plant height and ear height are basic characteristics regarding the suitability of mechanized harvesting. Plant height has a great importance because it determines the height that the hibrids will have. Also, plant height can determine how to use a hybrid for grain yield or silage, and it can influence plant resistance to falling and breaking. In our study, this character showed high variability with values ranging between $78 \mathrm{~cm}$ and $227 \mathrm{~cm}$. T 148 inbreed line was observed for the reduced height and TD 337 for the maximum height. After analyzing the histogram it has been observed that most of the lines (215) had values between 158 and $185 \mathrm{~cm}$, only 15 lines were between 78-128 cm height. The coefficient of variation has a value of 12.8 , which means middle variability.
Main ear insertion for the 471 inbred lines was observed at heights between $23 \mathrm{~cm}$ and $91 \mathrm{~cm}$, so that shows no problem for mechanized harvesting. Variability in the insertion was high, the coefficient of variation having a value of 22.2. the lowest insertion, $23 \mathrm{~cm}$ was for the inbreed line $\mathrm{T} 148$, the same line that had reduced plant height,while the maximul ear height was at the line T 443.

The average number of leaves / plant for the maize inbred lines belonging to the collection of the SCDA Turda was 12.6, with a minimum of nine (TA 24) and a maximum of 17 (TA 408), so it can be said that foliage is well developed. Variability on the number of leaves / plant was low, with a calculated coefficient of 8.7. CRISTEA (2004) said that the genotypes with a a well developed foliar sistem contain a higher quantity of organic substances comparing to the ones with a smaller surface area.

Among the plant characters, number of branches of the panicle presents the widest amplitude, with values ranging from 1 to 37 . TD 241 line was characterized by the minimum number of branches, while the line RT 442 presented a large number of branches, 37 . The coefficient of 56 shows a high variability. After analyzing the histogram it can be said that most of the maize inbred lines, 212 had between 7 and 13 branches/tassel, while only 5 lines had between 30 and 37 branches. After the research made in the past (Jugenheimer, 1976) it is

Tab. 1. Analysis of variance for the period of vegetation and plant traits in 471 maize inbred lines

\begin{tabular}{|c|c|c|c|c|c|c|}
\hline \multirow[b]{2}{*}{ Sources } & \multicolumn{2}{|c|}{ Sowing to } & \multirow[b]{2}{*}{ Plant height } & \multirow[b]{2}{*}{ Ear height } & \multirow{2}{*}{$\begin{array}{c}\text { No. of } \\
\text { leaves/ } \\
\text { plant }\end{array}$} & \multirow{2}{*}{$\begin{array}{l}\text { No. of } \\
\text { branches/ } \\
\text { tassel }\end{array}$} \\
\hline & silking & $\begin{array}{c}\text { Physiological } \\
\text { maturity }\end{array}$ & & & & \\
\hline & \multicolumn{2}{|c|}{$\left(\Sigma^{0} \mathrm{C}\right)\left(\mathrm{GDU}^{0} \mathrm{C}\right)$} & $\mathrm{cm}$ & $\mathrm{cm}$ & no. & no. \\
\hline Count & 471 & 471 & 471 & 471 & 471 & 471 \\
\hline Minimum & 492 & 911 & 78 & 23 & 9 & 1 \\
\hline Mean & 618.3 & 1077.5 & 165.8 & 54.0 & 12.6 & 10.9 \\
\hline Maximum & 745 & 1209 & 227 & 91 & 17 & 37 \\
\hline Standard Error & 1.9 & 2.7 & 0.9 & 0.5 & 0.1 & 0.3 \\
\hline Median & 613 & 1086 & 165 & 53 & 13 & 9 \\
\hline Standard Deviation & 41.1 & 57.9 & 21.3 & 12.0 & 1.1 & 6.1 \\
\hline Sample Variance & 1689.2 & 3358.5 & 454.5 & 144.2 & 1.2 & 36.7 \\
\hline $\begin{array}{c}\text { Confidence Level } \\
(95.0 \%)\end{array}$ & 3.7 & 5.2 & 1.9 & 1.1 & 0.1 & 0.5 \\
\hline $\begin{array}{c}\text { Coefficient of } \\
\text { variation (CV\%) }\end{array}$ & 6.6 & 5.4 & 12.8 & 22.2 & 8.7 & 56.0 \\
\hline
\end{tabular}


known that there is a negative correlation between the high number of branches/tassel and production capacity of the respective genotype.

Ear length for ARDS Turda inbreed lines has a coefficient of variability with a medium value (15.1), most lengths are between 14 and $16 \mathrm{~cm}$ (220 lines). Only 5 lines have ears with lengths between 8 and $10 \mathrm{~cm}$, so we can say that most lines have medium length ears. From the entire collection of maize inbred lines, TD 244 has the shortest ear lenght, $8 \mathrm{~cm}$, while the line TC 383 ear has an average length of $22 \mathrm{~cm}$.

The number of kernels rows is of particular importance in terms of production. In our study it was found middle variability (15.1), the values are between 8 (T9 line) and 24 rows (TE 319 line). Most inbreed lines (167) have 14-16 kernel rows, or 16-18 rows (145 lines).

The number of grains per row is another very important character in terms of breeding, and the studied maize lines presents middle variability (15.7). The minimum value is 11 kernels per row, the line TD 240 and maximum, 41kernels for TE 217 inbreed line, but most lines (239) have values between 24 and 28 grains/row.
Ear weight, a production character is another very important feature which presents a high variability, with a coefficient of 26.2 and values between 28 and 191 grams. For this character there were observed T148 lines (28 grams) and TB 363 line, 191 grams weight of main ear. 210 inbreed lines had between 91 and 122 grams.

Percent of grains/ear has a low variability, most inbreed lines (214) have values between 77 and $81 \%$. TD 240 had the lowest percent of grains/ear, $55 \%$, this aspect is closely related to the reduced number of kernels per row encountered in this line. The highest percent of grains/ear, 94 $\%$ was calculated for TD 364 and TA 426 inbreed lines.

Weight of 1000 grains is a trait with a high variability (20.8), with values between 103 and 386 grams. The lowest weight of 1000 grains was in the case of $\mathrm{T} 148$, line that was observed also for a reduced weight of the main ear. TA 409 registered the highest value for the weight of 1000 grains. 152 inbreed lines had between 212 and 252 grams.

Another essential trait of the maize ear with a high coefficient of variation (28.6) is the kernel depth, with values between 0.4 and $1.84 \mathrm{~cm}$. For

Tab. 2. Analysis of variance for ear traits in 471 maize inbred lines

\begin{tabular}{|c|c|c|c|c|c|c|c|c|c|c|c|}
\hline Sources & 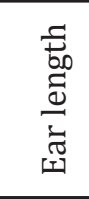 & $\begin{array}{l}n \\
3 \\
0 \\
0 \\
\dot{0}\end{array}$ & 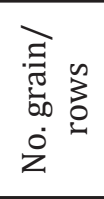 & 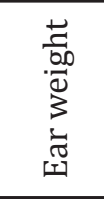 & 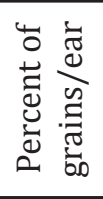 & 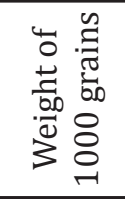 & 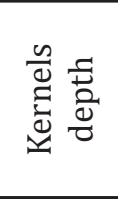 & 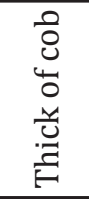 & 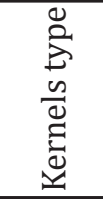 & $\begin{array}{l}\frac{n}{d} \\
\stackrel{0}{0} \\
\stackrel{0}{0}\end{array}$ & $\begin{array}{l}\dot{0} \\
0 \\
0 \\
0 \\
0\end{array}$ \\
\hline & $\mathrm{cm}$ & no & no & g & $\%$ & $\mathrm{~g}$ & $\mathrm{~cm}$ & $\mathrm{~cm}$ & grade & grade & grade \\
\hline Count & 471 & 471 & 471 & 471 & 471 & 471 & 471 & 471 & 471 & 471 & 471 \\
\hline Minimum & 8 & 8 & 11 & 28 & 55 & 103 & 0.4 & 1.6 & 1 & 3 & 1 \\
\hline Mean & 15.2 & 15.2 & 26.8 & 108 & 78.5 & 235.2 & 0.7 & 2.4 & 3.5 & 3.9 & 5.2 \\
\hline Maximum & 22 & 24 & 41 & 191 & 94 & 386 & 1.84 & 3.2 & 5 & 9 & 9 \\
\hline $\begin{array}{l}\text { Standard } \\
\text { Error }\end{array}$ & 0.1 & 0.1 & 0.2 & 1.3 & 0.3 & 2.3 & 0.007 & 0.01 & 0.07 & 0.03 & 0.1 \\
\hline Median & 15 & 15 & 27 & 108 & 79 & 237 & 0.7 & 2.4 & 4 & 4 & 7 \\
\hline $\begin{array}{l}\text { Standard } \\
\text { Deviation }\end{array}$ & 2.3 & 2.3 & 4.2 & 28.3 & 5.5 & 48.9 & 0.2 & 0.3 & 1.4 & 0.6 & 3.2 \\
\hline $\begin{array}{c}\text { Sample } \\
\text { Variance }\end{array}$ & 5.5 & 5.3 & 17.9 & 800.1 & 30.0 & 2391.6 & 0.03 & 0.8 & 2.1 & 0.4 & 10.2 \\
\hline $\begin{array}{c}\text { Confidence } \\
\text { Level (95.0\%) }\end{array}$ & 0.2 & 0.2 & 0.4 & 2.5 & 0.5 & 4.4 & 0.02 & 0.3 & 0.1 & 0.1 & 0.3 \\
\hline $\begin{array}{l}\text { Coefficient } \\
\text { of variation } \\
\text { (CV\%) }\end{array}$ & 15.1 & 15.1 & 15.7 & 26.2 & 7.0 & 20.8 & 28.6 & 18.8 & 40.0 & 15.4 & 61.5 \\
\hline
\end{tabular}


the $0.4 \mathrm{~cm}$ value there were observes the lines: $\mathrm{T} 122, \mathrm{~T} 139, \mathrm{~T} 147$ and TC 350, and for the maximum value of $1.84 \mathrm{~cm}$ the line TA 448 . From all 471 studied inbreed lines, 239 had the kernel depth between 0.7 and 0.8 .

The thick of cob for the studied lines had values between 1.6 and $3.2 \mathrm{~cm}$, showing a middle variability. Atfer the analysis of the histogram, there were identified 184 inbreed lines with a thick of the cob of 2.2-2.4 cm. The lowest dimensions of the cob were observes at T 148 line, while TC235, TE 203A, TE 204 and TC 350 had the highest values, $3.2 \mathrm{~cm}$.

A high coefficient of variation (40) was identified for kernel type. 175 lines had semident kernels, 138 dent, 99 flint and 59 semi-flint kernels.

Regarding the color of the kernels, most lines, 320 had dark yellow kernels, 102 normal yellow kernels, 44 yellow-orange kernels. There were also identified 3 inbreed lines with orange kernels (TE 265, TA 408 and TA 463) and one with reddish kernels (RTB 240) and one line with red kernels (TD 283).

Most inbreed lines from this study have red cob (219), 164 white, 84 dark red and only 4 lines have pink cob.

\section{CONCLUSIONS}

- The vegetation period had a high variability, which indicates the existence of several groups of precocity in the lines collection.

- The low number of branches in the panicle is intended to improve agronomic character and most of the lines from SCDA Turda have one to 7 branches, the minimum being only a branch (TD 241). Of all analyzed traits, the number of branches/tassel had the highest coefficient of variation, 56 , which indicates a high variability between the lines.

- Inbred lines ears were sized with an average length of $15.2 \mathrm{~cm}$ and average weight of 108 grams. TC Line 383 was observed by a length of $22 \mathrm{~cm}$, and TB 363 with a weight of 191 grams.

- Weight of 1000 grains has high values, 152 inbred lines had between 212 and 252 grams, remarking TA 409 with 386 grams.

- There was observed a very high coefficient of variation (40) for kernel type. 175 lines had semi-dent kernels, 138 dent, 99 flint and 59 semi-flint.

- Regarding the color if the kernels, most lines, 320, had dark yellow kernels, but there are also lines with yellow, orange, reddish or red kernels.

- On ARDS Turda maize inbreed lines collection there are lines with red cob but also white cob.

\section{REFERENCES}

1. Ardelean M (2008). Principii ale metodologiei cercetării agronomice și medical veterinare. Editura AcademicPres: 27-35 Cluj- Napoca

2. Căbulea I (1987). Unele aspecte ale orientării lucrărilor de ameliorare a porumbului. Contrib. cercet. științ. dezvolt. agric. (1957-1987), S.C.A. Turda:169-187

3. Căbulea I, Grecu C, Haș I, Haș V, Copândean A, Teban A (1999). Crearea hibrizilor de porumb la S.C.A. Turda în perioada 1983-1987. Contrib. cercet. ştiinț. desvolt. agric:73-98

4. Ceapoiu N (1968). Metode statistice aplicate în experiențele agricole şi biologice. Ed. Agro-Silvică București.

5. Cristea M (2004). Fiziologia porumbului, în Porumbulstudiu monografic, Editura Academiei Române:104-114.

6. Haş I (1992). Cercetări privind rolul formelor parentale diferențiate genetic în realizarea heterozisuluila porumb. Teză de doctorat, USAMV Cluj-Napoca.

7. Haș V, Căbulea I, Haș I, Copândean A (1999). Progresul genetic realizat în crearea linilor consangvinizate de porumb la S.C.A. Turda. Contribuții ale cercetării științifice la dezvoltarea agriculturii, vol. VI, S.C.A. Turda:99-112.

8. Jugenheimer $\mathrm{R}$ (1976). Corn, Improvement, Seed Production, and Uses, A Wiley-Interscience Publication, New York.

9. Hallauer A, Miranda JB (1981). Quantitative genetics in maize breeding. Iowa State University Press, Ames, USA. 